\title{
NON-RANDOM MATING IN WILD POPULATIONS OF POLYMORPHIC ADALIA BIPUNCTATA
}

\author{
JOHN MUGGLETON* \\ Department of Genetics, University of Nottingham, Nottingham NG7 2RD
}

Received 6.vii.78

\begin{abstract}
SUMMARY
The nature of the factors maintaining the colour polymorphism in Adalia bipunctata has been the subject of much discussion and in some populations a tendency for the melanic morphs to mate more frequently than the nonmelanics has been reported. The morph frequencies among mating pairs in wild populations of $A$. bipunctata in England have been scored and analysed in order to discover whether mating between morphs is a random process. Data from the literature are also analysed in the same way and the methods of analysis adopted by earlier workers are discussed. It is concluded that mating between morphs is frequency dependent so that it is the rare morph in the population, regardless of colour, which mates more frequently. This appears to be a further method by which the polymorphism in this species is maintained.
\end{abstract}

\section{INTRODUCTION}

A visual polymorphism exists in Adalia bipunctata L. (two-spot ladybird) in which there are a number of morphs for the pattern and colour of the elytra and pronotum. These morphs are under the control of at least 11 alleles at a single locus, and the elytral colour patterns range from black with two red spots (sublunata) to all red (impunctata). The black forms (melanics) are dominant to the red forms (non-melanics) (Lusis 1928, 1932). In Europe the most frequent melanic morphs are 4-maculata and 6-pustulata (black with four and six red spots respectively) and the commonest nonmelanic is typica (red with two black spots). Nearly all populations are polymorphic. In the British Isles the percentage of melanics in populations varies geographically, and exceeds 90 per cent in Manchester and Glasgow (Bishop, Cook and Muggleton, 1978; Creed, 1971). It seems probable that a number of factors are responsible for maintaining the polymorphism (Muggleton, 1978) and that a major factor determining the frequency of melanics is their more efficient absorption of solar radiation, resulting in a relatively greater activity (Lusis, 1961; Muggleton, Lonsdale and Benham, 1975). Creed $(1971,1975)$ however, has argued against the dominating importance of heat absorption and has suggested that the melanics are more tolerant of air pollution.

Mating pairs are often seen during the collection of samples. Lusis (1961) reported data on the frequencies of morphs among mating pairs in samples from Riga and Moscow. He compared the frequencies of morphs in the mating pairs with those in the populations from which they came,

* Present address: M.A.F.F., Pest Infestation Control Laboratory, London Road, Slough, Berks. SL3 7HJ 
finding that there was an excess of melanics in the mating pairs. He concluded that this excess was the result of the melanics' greater activity in sunlight, and suggested that it gave them an advantage which could account for the increase in their frequency during the summer reported by Timoféeff-Ressovsky (1940) for populations in Berlin. In contrast Creed (1975) analysed data from Britain and Western Europe, including his own observations and those of Meissner (1907a, $b ; 1909)$, but found no evidence for a significant excess of melanics among mating pairs.

Lusis' (1961) interpretation of the melanic excess has been accepted by other authors (Hodek, 1973; Muggleton et al., 1975). However, further information, when considered with the earlier data, suggests that the greater activity of the melanics may not be the reason for their excess among mating pairs. Instead there is evidence for frequency dependent effects in mating.

\section{Materials and methods}

While collecting random samples of Adalia bipunctata at various localities in England during 1976 and 1977 I noted the morphs of each male and female found copulating. During copulation the male is carried on the back of the female and thus the sexes can be distinguished. The samples were collected from low growing vegetation between April and July. Specimens were searched for by eye. Mating pairs appeared to be as visible as non-mating animals. Most of the 51 sites were sampled on a single occasion.

\section{Analysis of data}

Lusis (1961) and Creed (1975) analysed their results by combining all the melanic and non-melanic morphs into two classes (black and red) and then comparing the observed frequencies of the different combinations of these classes in the mating pairs with expected frequencies calculated from the complete sample. For each locality and year, Lusis' data consist of repeated samples from the same population (the samples were not removed) which were then combined. Creed's data consist of small samples from a number of sites; he calculated the expected values for each site and as these were small he combined all the observed and expected values in order to carry out a chi ${ }^{2}$ analysis. He repeated this procedure for the daily samples from Potsdam recorded by Meissner (1907a, $b ; 1909)$.

O'Donald (pers. comm.) has pointed out to me that the method of analysis adopted by Lusis and Greed is unsatisfactory for two reasons. Firstly, it confounds two possible effects which could lead to non-random mating. These are, an excess of one morph mating relative to morph frequency in the sampled population, and non-random mating among the mating animals. Secondly, their method of analysis is not valid because the expected values are based on samples which are themselves subject to sampling errors. A further objection is that the lumping of what may be heterogeneous data could mask frequency dependent effects if these were present. It therefore seemed appropriate to find some alternative way of analysing these types of data and the methods I have used are outlined below.

The first method tests for randomness within pairs and shows whether any non-random effect is due to an excess of like or unlike matings. In 
this test the expected values for the three combinations of melanic and nonmelanic morphs in mating pairs are calculated from the morph frequency of the mating animals and compared to the observed values. The expected values can be calculated for each sample. However, in most cases the samples are too small for $\mathrm{chi}^{2}$ analyses to be carried out and in order that this may be done the data have been combined. To overcome the problem of combining what may be heterogeneous data the samples were grouped into classes according to the melanic frequency of the sample from which they were derived. The second method I have used examines whether there is an excess of one morph among the mating animals compared to those that are not mating. The following $2 \times 2$ table is tested by $\mathrm{chi}^{2}$.

$\begin{array}{lcc} & \text { melanic } & \text { non-melanic } \\ \text { mating animals } & \mathrm{a} & \mathrm{b} \\ \text { non-mating animals } & \mathrm{c} & \mathrm{d}\end{array}$

Again as the numbers in many samples are small the data have been combined into classes according to the melanic frequency in the whole sample. So that each sample could be evaluated individually for an excess of one morph mating, a third method of analysis was used. This involved calculating a cross product ratio for the individual samples in the following way:

$$
\frac{\text { number of non-melanics in sample }}{\text { number of melanics in sample }} \times \frac{\text { number of melanics mating }}{\text { number of non-melanics mating }}
$$

A value greater than one indicates an excess of melanics among mating animals and a value less than one indicates an excess of non-melanics. As there is a difference in scaling between the values less than one (which may range from zero to one) and the values greater than one (which may range from one to infinity) the natural logarithm of the cross product ratio has been used in this paper.

\section{Results}

The data I collected in 1976 and 1977 together with those of Meissner $(1907 a, b ; 1909)$ from Potsdam were analysed by the three methods described above. Lusis' (1961) data consists of combined samples for each site and so cannot be used for the $\mathrm{chi}^{2}$ analyses as there is no way of knowing whether there is any heterogeneity in the samples. The cross product ratio value has, however, been calculated for each of his Moscow and Riga sites as this is a more conservative test. Creed's (1975) data cannot be used as they are from heterogeneous samples and there is no information on the non-mating part of the sample.

Table 1 shows the observed and expected values used to test for random mating amongst the mating animals. The values for each locality have been combined into one of six groups as outlined above. The data from my collections and those from Potsdam are detailed separately and then combined for the $\mathrm{chi}^{2}$ analysis. Table 2 shows the morph frequency in the mating and non-mating parts of the samples and the samples are combined into one of seven groups. Fig. 1 shows the natural logarithms of the cross product ratio for the 86 samples for which this calculation can be made, plotted against the angular transformation of the percentage of melanics in 
the samples from which the mating pairs were taken. The regression line of the $\log _{e}$ cross product ratio on the percentage of melanics is also shown.

\section{Discussion}

The comparison of the observed and expected values of morphs among the mating pairs indicates that mating is taking place at random in all frequency classes (table 1). There is no evidence of heterogeneity between the data from England and Potsdam. On the other hand the comparison of morph frequencies in the mating and non-mating parts of the samples (table 2) shows a significant excess of melanics in the mating pairs in three frequency classes (0-10 per cent, $10 \cdot 1-20$ per cent and $30 \cdot 1-40$ per cent) and a significant excess of non-melanics in the mating pairs in one class (50.160 per cent). Again there is no evidence of heterogeneity between the data from England and Potsdam.

The results confirm Lusis' conclusion (1961) that mating does not take place at random with respect to the frequencies in the whole population. They indicate, however, that this is due to an excess of one morph mating rather than to non-random mating amongst the mating population. For the present data, Lusis' finding that it was the melanic morphs that made up the excess is true only when melanic frequencies are less than 0.5 . When melanic frequencies exceed 0.5 it is the typical morph which is in excess. A difference such as this could be due to a difference in morph frequency between the sexes. There is, however, no evidence of such differences in

TABLE 1

Observed and expected numbers of the combinations of melanic $(m)$ and non-melanic $(n-m)$ morphs in mating pairs for each of six frequency classes. Chi ${ }^{2}$ values are for the combined England and Potsdam data

\begin{tabular}{|c|c|c|c|c|c|c|c|c|}
\hline \multirow[b]{2}{*}{ Locality } & \multirow{2}{*}{$\begin{array}{c}\text { Melanic } \\
\text { frequency } \\
\text { in whole } \\
\text { sample }(\%)\end{array}$} & \multicolumn{3}{|c|}{$\begin{array}{l}\text { Observed number of } \\
\text { mating pairs }\end{array}$} & \multicolumn{3}{|c|}{$\begin{array}{l}\text { Expected number of } \\
\text { mating pairs }\end{array}$} & \multirow[b]{2}{*}{$\mathrm{Chi}^{2}$} \\
\hline & & $\mathrm{m} \times \mathrm{m}$ & $\mathrm{m} \times \mathrm{n}-\mathrm{m}$ & $\mathrm{n}-\mathrm{m} \times \mathbf{n}-\mathbf{m}$ & $\mathrm{m} \times \mathrm{m}$ & $\mathrm{m} \times \mathrm{n}-\mathrm{m}$ & $\mathrm{n}-\mathrm{m} \times \mathrm{n}-\mathrm{m}$ & \\
\hline England & $0-10 \cdot 0$ & 1 & 43 & 200 & $2 \cdot 7$ & $39 \cdot 9$ & $201 \cdot 4$ & \\
\hline Potsdam & & - & - & $\overrightarrow{0}$ & - & $\overrightarrow{0}$ & - & \\
\hline Combined & & 1 & 43 & 200 & $2 \cdot 7$ & $39 \cdot 9$ & $201 \cdot 4$ & $1 \cdot 321$ \\
\hline England & $10 \cdot 1-20 \cdot 0$ & 6 & 31 & 58 & $5 \cdot 3$ & $31 \cdot 6$ & $58 \cdot 1$ & \\
\hline Potsdam & & 0 & 1 & 2 & 0.75 & $1 \cdot 5$ & $0 \cdot 75$ & \\
\hline Combined & & 6 & 32 & 60 & $6 \cdot 05$ & $33 \cdot 1$ & $58 \cdot 85$ & $0 \cdot 059$ \\
\hline England & $20 \cdot 1-30 \cdot 0$ & 4 & 12 & 15 & $4 \cdot 5$ & $13 \cdot 7$ & $13 \cdot 7$ & \\
\hline Potsdam & & 2 & 7 & 6 & $2 \cdot 4$ & $6 \cdot 2$ & $6 \cdot 4$ & \\
\hline Combined & & 6 & 19 & 21 & $6 \cdot 9$ & $19 \cdot 9$ & $20 \cdot 1$ & $0 \cdot 198$ \\
\hline England & $30 \cdot 1-40 \cdot 0$ & 0 & 5 & 1 & $0 \cdot 8$ & $2 \cdot 3$ & $1 \cdot 8$ & \\
\hline Potsdam & & 10 & 24 & 7 & $12 \cdot 4$ & $19 \cdot 3$ & $10 \cdot 3$ & \\
\hline Combined & & 10 & 29 & 8 & $13 \cdot 2$ & $21 \cdot 6$ & $12 \cdot 1$ & $4 \cdot 70^{*}$ \\
\hline England & $40 \cdot 1-50 \cdot 0$ & 3 & 1 & 3 & $1 \cdot 75$ & $1 \cdot 5$ & $1 \cdot 75$ & \\
\hline Potsdam & & 24 & 43 & 33 & $21 \cdot 3$ & $48 \cdot 5$ & $30 \cdot 2$ & \\
\hline Combined & & 27 & 44 & 36 & $23 \cdot 05$ & $50 \cdot 0$ & $31 \cdot 95$ & $1 \cdot 910$ \\
\hline England & $>50 \cdot 0$ & 7 & 10 & 1 & $8 \cdot 5$ & $6 \cdot 9$ & $2 \cdot 5$ & \\
\hline Potsdam & & 5 & 15 & 12 & $5 \cdot 9$ & $15 \cdot 2$ & $10 \cdot 9$ & \\
\hline Combined & & 12 & 25 & 13 & $14 \cdot 4$ & $22 \cdot 1$ & 13.4 & 0.792 \\
\hline
\end{tabular}

* $\mathrm{P}<0 \cdot 05, \mathrm{chi}^{2}$ with one degree of freedom. 
TABLE 2

Numbers of melanics and non-melanics in the mating and non-mating parts of samples for each of seven frequency classes. $C h i^{2}$ values are for the combined England and Potsdam data

\begin{tabular}{|c|c|c|c|c|c|c|}
\hline \multirow[b]{2}{*}{ Locality } & \multirow{2}{*}{$\begin{array}{c}\text { Melanic } \\
\text { frequency } \\
\text { in whole } \\
\text { sample }(\%)\end{array}$} & \multicolumn{2}{|c|}{ Number of mating animals } & \multicolumn{2}{|c|}{$\begin{array}{c}\text { Number of } \\
\text { non-mating animals }\end{array}$} & \multirow[b]{2}{*}{$\mathrm{Chi}^{2}$} \\
\hline & & non-melanic & melanic & non-melanic & melanic & \\
\hline England & $0-10 \cdot 0$ & 536 & 44 & 1597 & 88 & \\
\hline Potsdam & & - & - & - & - & \\
\hline Combined & & 536 & 44 & 1597 & 88 & $4 \cdot 39 *$ \\
\hline England & $10 \cdot 1-20 \cdot 0$ & $\begin{array}{r}151 \\
5\end{array}$ & 43 & $\begin{array}{r}533 \\
3\end{array}$ & 66 & \\
\hline $\begin{array}{l}\text { Potsdam } \\
\text { Combined }\end{array}$ & & $\begin{array}{r}5 \\
156\end{array}$ & $\begin{array}{r}1 \\
44\end{array}$ & $\begin{array}{r}3 \\
536\end{array}$ & $\begin{array}{r}1 \\
67\end{array}$ & $14.95 * * *$ \\
\hline England & $20 \cdot 1-30 \cdot 0$ & 44 & 20 & 200 & 69 & \\
\hline Potsdam & & 19 & 11 & 119 & 41 & \\
\hline Combined & & 63 & 31 & 319 & 110 & $2 \cdot 11$ \\
\hline England & $30 \cdot 1-40 \cdot 0$ & 6 & 4 & 48 & 27 & \\
\hline Potsdam & & 40 & 44 & 207 & 99 & \\
\hline Combined & & 46 & 48 & 255 & 126 & $10 \cdot 52 * *$ \\
\hline England & $40 \cdot 1-50 \cdot 0$ & 7 & 7 & 43 & 32 & \\
\hline Potsdam & & 109 & 91 & 398 & 322 & \\
\hline Combined & & 116 & 98 & 441 & 354 & $0 \cdot 11$ \\
\hline England & $50 \cdot 1-60 \cdot 0$ & 3 & 1 & 14 & 24 & \\
\hline Potsdam & & 37 & 27 & 61 & 82 & \\
\hline Combined & & 40 & 28 & 75 & 106 & $6 \cdot 01^{*}$ \\
\hline England & $>60 \cdot 0$ & 9 & 23 & 10 & 63 & \\
\hline Potsdam & & - & - & - & - & \\
\hline Combined & & 9 & 23 & 10 & 63 & $3 \cdot 12$ \\
\hline
\end{tabular}

the data under discussion; 21 per cent of the males are melanic compared with 24 per cent of the females. If Lusis' (1961) data from Moscow and Riga are included 38 per cent of the males are melanic compared with 39 per cent of the females.

That there is an excess of one class of morphs among the mating animals when it is the less common of the two classes in the whole population suggests that ability to mate may be frequency dependent. Creed (1975) pointed out that on the basis of his calculations the deficiency of typicals among the mating animals was greater in Moscow than in Riga or Potsdam. An examination of the cross product ratio values (fig. 1) shows a relationship between melanic frequency and the natural logarithm of the cross product ratio. As the melanic frequency increases, the cross product ratio value decreases and the regression of the natural logarithm of the cross product ratio on melanic frequency is highly significant $(t=5 \cdot 24, n=86, \mathrm{P}<0 \cdot 001)$. Thus ability to mate appears to be frequency dependent and it is the rare morph, regardless of colour, which is in excess among the mating pairs. Indeed, the frequency dependent effect may be more marked than appears from this analysis. The theoretical distribution of the cross product ratio values is skewed so that when one class is rare there will be a tendency for the value obtained to be smaller than if the values were normally distributed. Thus the analysis is biased against finding an excess of the rare class. 


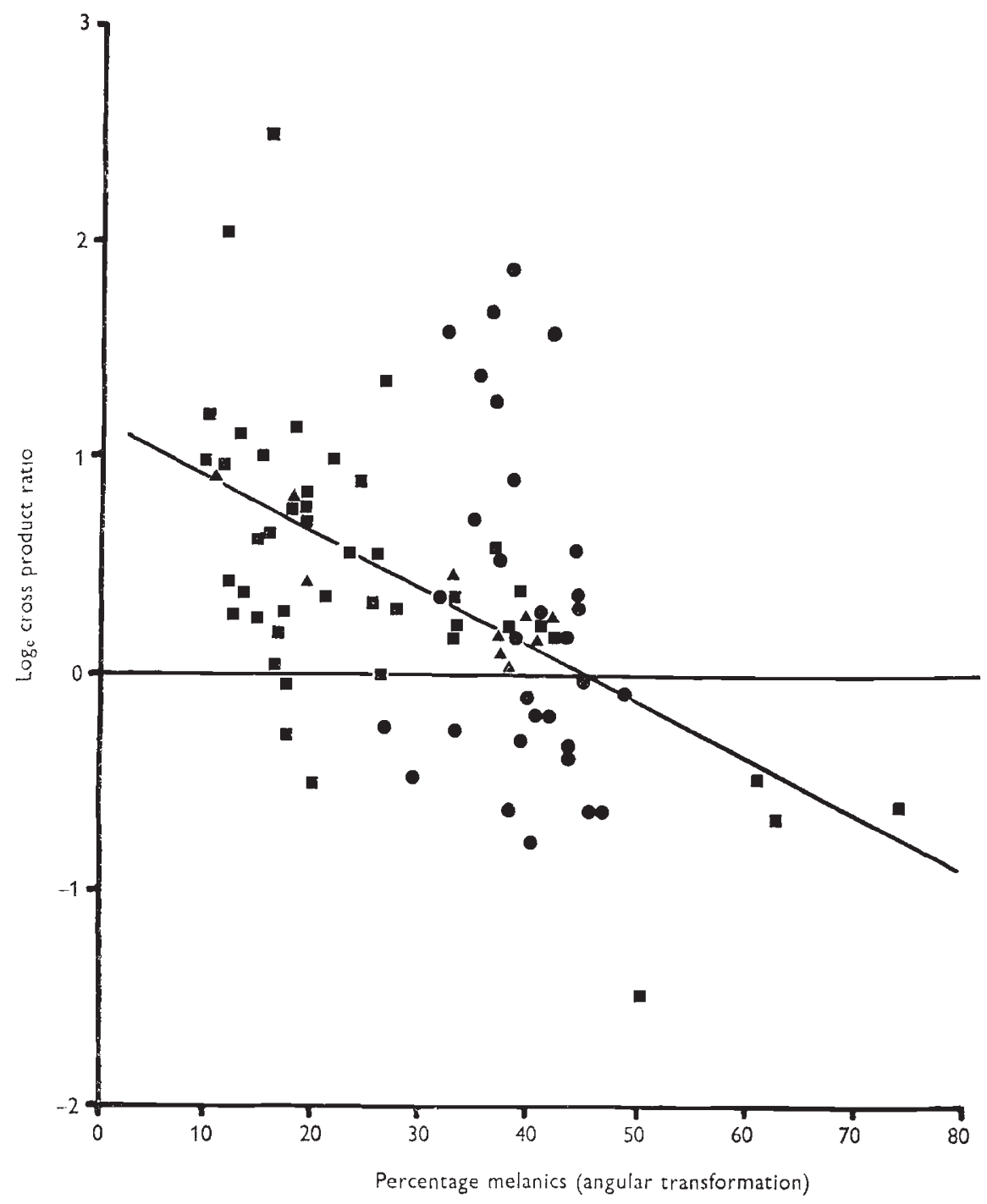

Fig. 1.-The natural logarithm of the cross product ratio of the two classes of morph in the mating part of the sample and the whole sample plotted against the angular transformation of the percentage of the melanic morph in the whole sample. The regression line is also shown $(y=1.96+-0.026 x)$. Cross product ratio values $>1$ indicate an excess of melanics in the mating pairs, values $<1$ indicate an excess of non-melanics. The samples were collected in Moscow and Riga (A), Potsdam (O) and England ( $\mathbf{0}$ ).

Frequency dependence of this type could occur if the animals mated more than once and if there was a preference for mating between unlike morphs (Cook, 1971). Alternatively, O'Donald $(1977 a, b)$ has shown that frequency dependence in mating will follow if the males mate more than once and the females exhibit constant mating preferences for particular morphs or genotypes. In this model preferences may occur between like as well as unlike 
morphs and O'Donald has been able to fit this model to examples of frequency dependent mating in laboratory populations of Drosophila pseudoobscura. However, examination of the present data shows no evidence of the excesses of certain mating combinations that would be expected if there was some form of mating preference. A preference for unlike matings could be masked by the grouping into two classes. This is particularly so for the melanic $\times$ melanic matings which include combinations of at least two morphs (quadrimaculata and sexpustulata). The numbers of the different melanic morphs are not given in earlier papers and so the only data available are those collected in the course of the present work. These data are presented in table 3 as observed and expected numbers of mating pairs. There are no consistent excesses of unlike matings, although six out of the 14 melanic $\times$ melanic matings are between unlike melanic morphs. The non-melanic

TABLE 3

Observed and expected numbers of the combinations of quadrimaculata ( $4 m)$, sexpustulata $(6 p)$ and non-melanic $(n-m)$ in mating pairs for each of six frequency classes

\begin{tabular}{|c|c|c|c|c|c|c|c|}
\hline \multirow{2}{*}{\multicolumn{2}{|c|}{$\begin{array}{l}\text { Melanic } \\
\text { frequency } \\
\text { in whole } \\
\text { sample }(\%)\end{array}$}} & \multicolumn{6}{|c|}{ Number of mating pairs } \\
\hline & & $4 \mathrm{~m} \times 4 \mathrm{~m}$ & $4 m \times 6 p$ & $4 m \times n-m$ & $6 \mathrm{p} \times 6 \mathrm{p}$ & $6 p \times n-m$ & $\mathrm{n}-\mathrm{m} \times \mathrm{n}-\mathrm{m}$ \\
\hline $0-10 \cdot 0$ & $\begin{array}{l}\text { obs. } \\
\text { exp. }\end{array}$ & $\begin{array}{l}I \\
1 \cdot 2\end{array}$ & $\begin{array}{l}0 \\
0.6\end{array}$ & $\begin{array}{l}25 \\
24 \cdot 1\end{array}$ & $\begin{array}{l}0 \\
1 \cdot 0\end{array}$ & $\begin{array}{l}18 \\
15 \cdot 4\end{array}$ & $\begin{array}{l}200 \\
201 \cdot 7\end{array}$ \\
\hline $10 \cdot 1-20 \cdot 0$ & $\begin{array}{l}\text { obs. } \\
\text { exp. }\end{array}$ & $\begin{array}{l}1 \\
2 \cdot 1\end{array}$ & $\begin{array}{l}5 \\
2 \cdot 2\end{array}$ & $\begin{array}{l}18 \\
18 \cdot 6\end{array}$ & $\begin{array}{c}0 \\
1 \cdot 2\end{array}$ & $\begin{array}{l}13 \\
13 \cdot 5\end{array}$ & $\begin{array}{l}58 \\
57 \cdot 4\end{array}$ \\
\hline $20 \cdot 1-30 \cdot 0$ & $\begin{array}{l}\text { obs. } \\
\text { exp. }\end{array}$ & $\begin{array}{l}3 \\
2 \cdot 7\end{array}$ & $\begin{array}{l}1 \\
0.6\end{array}$ & $\begin{array}{l}10 \\
11 \cdot 9\end{array}$ & $\begin{array}{l}0 \\
0 \cdot 1\end{array}$ & $\begin{array}{l}1 \\
1 \cdot 3\end{array}$ & $\begin{array}{c}16 \\
14 \cdot 4\end{array}$ \\
\hline $30 \cdot 1-40 \cdot 0$ & $\begin{array}{l}\text { obs. } \\
\text { exp. }\end{array}$ & $\begin{array}{l}0 \\
1 \cdot 1\end{array}$ & - & $\begin{array}{l}5 \\
2 \cdot 8\end{array}$ & - & - & $\begin{array}{l}1 \\
2 \cdot 1\end{array}$ \\
\hline $40 \cdot 1-50 \cdot 0$ & $\begin{array}{l}\text { obs. } \\
\text { exp. }\end{array}$ & $\begin{array}{l}3 \\
1.3\end{array}$ & $\begin{array}{l}0 \\
0.4\end{array}$ & $\begin{array}{l}0 \\
3 \cdot 0\end{array}$ & $\begin{array}{l}0 \\
0 \cdot 1\end{array}$ & $\begin{array}{l}1 \\
0.5\end{array}$ & $\begin{array}{l}3 \\
1.7\end{array}$ \\
\hline$>50 \cdot 0$ & $\begin{array}{l}\text { obs. } \\
\text { exp. }\end{array}$ & $\begin{array}{l}6 \\
7 \cdot 5\end{array}$ & - & $\begin{array}{l}10 \\
6.9\end{array}$ & - & - & $\begin{array}{l}1 \\
2 \cdot 5\end{array}$ \\
\hline
\end{tabular}

class also includes the annulata morph (sensu Lusis, 1932; see Creed, 1966, fig. 1, 5-8) which may make up 10 per cent of some populations, but this morph was not usually scored in the mating pairs. On the occasions when it was scored, three out of 12 non-melanic $\times$ non-melanic matings involved annulata.

If the interpretation of non-random mating in $A$. bipunctata on a frequency dependent basis involving a mating preference is correct, then there may be no advantage given to melanics during mating by their greater activity (Lusis, 1961) or the advantage may be much less important than previously supposed. In which case the selective advantage afforded to melanics by their greater activity will have to be explained in other terms. Muggleton et al. (1975) suggested that feeding activity of the melanics may be greater and there is experimental evidence that this is so (Muggleton, in preparation). Alternatively the frequency dependent effect could be the consequence of a tendency, in areas where melanics are rare, for them to be at their most active, because in these areas solar radiation is generally high 
and therefore melanics may mate more frequently than in areas where they are common, but less active. On the other hand for these observations to be explained in this way the relative activity of melanics to non-melanics would have to be higher in those areas where melanics are rare than in those areas where they are common. In this respect it would be interesting to know what happens in localities where melanics are common and sunshine levels are high (e.g. northern Italy). If the same pattern of mating occurs in these localities as in those examined in this paper this would be further confirmation of a frequency dependent effect.

Lusis (1961) proposed that the increase in frequency of melanics during the summer in Berlin, reported by Timoféeff-Ressovsky (1940), could be explained by the more frequent mating of the melanics in the course of several generations during the summer. If the excess of melanics is the result of genuine frequency dependent mating rather than greater activity, then in areas where non-melanics are rare it might be expected that there would be an increase of non-melanics during the summer, the reverse of the Berlin situation. However, as the non-melanics are recessive such an increase may be difficult to detect.

Eanes et al. (1977) report what appears to be frequency dependent sexual selection in the milkweed beetle, Tetraopes tetraophthalmus. They calculated a value they term mating fitness which for the data in the present paper would be analogous to my cross product ratio value. Although the range of gene frequencies in the populations they studied is smaller than that examined in the present paper the results of their comparisons of mating fitness with genotype frequency are similar to the results illustrated in fig. 1 . Their ability to determine the genotype of the animals examined enabled them to make a more thorough analysis of their data than has been possible for my data. On the other hand, they point out that the use of enzyme loci in T. tetraophthalmus presents certain difficulties in this type of study and so visual polymorphism in $A$. bipunctata may prove to be a better vehicle for the study of sexual selection in wild populations than enzyme polymorphisms. The data from $A$. bipunctata remains unique in that it appears to be the first time in a wild population that the advantage to one of two morphs has been shown to decline as its frequency increases and be replaced by an advantage to the other morph.

In an earlier paper I pointed out that many factors are probably involved in maintaining polymorphism in A. bipunctata (Muggleton, 1978). The existence of frequency dependent mating between the morphs would provide yet another mechanism for maintaining this polymorphism. Indeed, it may be argued that this is the only mechanism whose existence has been confirmed.

Acknowledgments.- I am grateful to Dr P. O'Donald for pointing out the difficulties involved in analysing the data presented in this paper. The methods I have adopted for analysing the mating frequencies owe much to discussions with Prof. B. C. Clarke, Drs L. M. Cook and D. T. Parkin and I am very grateful to them for their assistance. This paper forms part of a thesis to be submitted for the Ph.D. degree of the University of Nottingham and I should like to thank my supervisor, Prof. B. C. Clarke, and Dr. E. R. Greed for reading and commenting on drafts of this paper. Dr D. T. Parkin kindly provided facilities in the Department of Genetics while this paper was being written. The work was done while I was in receipt of an S.R.C. Studentship. 


\section{REFERENGES}

BISHOP, J. A., COOK, L. M., AND MUGGLETON, J. 1978. The response of two species of moths to industrialisation in north west England. I. Polymorphism for melanism. Phil. Trans. R. Soc. Lond. B, 281, 489-515.

Cook, L. M. 1971. Coefficients of Natural Selection. Hutchinson, London.

CREED, E. R. 1966. Geographic variation in the two-spot ladybird in England and Wales. Heredity, 21, 57-72.

CREED, E. R. 1971. Melanism in the two-spot ladybird, Adalia bipunctata, in Great Britain. In Ecological Genetics and Evolution, ed. E. R. Creed, pp. 134-151. Blackwell Scientific Publications, Oxford.

CREED, E. R. 1975. Melanism in the two-spot ladybird: the nature and intensity of selection. Proc. R. Soc. Lond. B, 190, 135-148.

EANES, W. F., GAFFNEY, P. M., KOEHN, R. K., AND SIMON, C. M. 1977. A study of sexual selection in natural populations of the milkweed beetle, Tetraopes tetraophthalmus. In Lecture Notes in Biomathematics 19: Measuring Selection in Natural Populations, ed. F. B. Christiansen and T. M. Fenchel, pp. 49-64. Springer-Verlag, Berlin.

HoDEK, I. 1973. Biology of Coccinellidae. Academia, Prague.

LUS, J. J. (LUSIS). 1928. On inheritance of colour and pattern in ladybeetles Adalia bipunctata and Adalia decimpunctata. Izv. Byuro Genet. Leningrad, 6, 89-163.

LUS, J. J. (LUSIS). 1932. An analysis of the dominance phenomenon in the inheritance of the elytra and pronotum colour in Adalia bipunctata. Trudy Lab. Genet., 9, 135-162.

LUSIS, J. J. 1961. On the biological meaning of colour polymorphism of ladybeetle Adalia bipunctata L. Latv. Ent., 4, 3-29.

MEISSNER, o. 1907a. Die relative Häufigkeit der Varietäten von Adalia bipunctata L. in Potsdam (1906). Z. wiss. InsektBiol., 3, 12-20, 39-45.

MEISSNER, O. 1907b. Die relative Häufigkeit der Varietäten von Adalia bipunctata L. in Potsdam (1907). Z. wiss. InsektBiol., 3, 309-313, 334-344, 369-374.

MEISSNER, o. 1909. Die relative Häufigkeit der Varietäten von Adalia bipunctata L. in Potsdam (1908). Z. wiss. InsektBiol., 5, 231-242.

MUGGLEToN, J. 1978. Selection against the melanic morphs of Adalia bipunctata (two-spot ladybird): a review and some new data. Heredity, 40, 268-290.

MUgGleton, J., Lonsdale, D., AND BENHAM, B. R. 1975. Melanism in Adalia bipunctata L. (Col. Coccinellidae) and its relationship to atmospheric pollution. 7. Appl. Ecol., 12, 451-464.

O'Donald, P. 1977a. Theoretical aspects of sexual selection. Theor. Pop. Biol., 12, 298-334.

o'DonAld, P. 1977b. Advantage of rare males in models of sexual selection. Nature, 267, 151-154.

TIMOFÉEFF-REssovsky, N. w. 1940. Zur Analyse des Polymorphismus bei Adalia bipunctata L. Biol. Zbl., 60, 130-137. 